\title{
HOAX DALAM PERSPEKTIF HINDU
}

\author{
I Komang Mertayasa \\ Institut Agama Hindu Negeri Tampung Penyang Palangkaraya \\ komang_mertayasa19@yahoo.com
}

\begin{tabular}{|c|c|}
\hline \multicolumn{2}{|c|}{$\begin{array}{l}\text { Riwayat Jurnal } \\
\text { Artikel diterima : } 13 \text { Juni } 2019 \\
\text { Artikel direvisi : } 25 \text { Juni } 2019 \\
\text { Artikel disetujui : 25 Juni } 2019\end{array}$} \\
\hline $\begin{array}{l}\text { Kata Kunci: } \\
\text { Perspektif Hindu } \\
\text { Berita Bohong } \\
\text { Hoax }\end{array}$ & $\begin{array}{l}\text { Abstrak } \\
\text { Peredaran hoax sangat cepat karena beberapa pengguna media } \\
\text { sosial membagikan tanpa membaca atau mengetahui lebih } \\
\text { mendalam apakah itu benar atau tidak. Peningkatan Literasi dapat } \\
\text { dilakukan dengan baik apabila seseorang memiliki pengetahuan } \\
\text { keagamaan yang memadai. Ajaran agama hindu memiliki } \\
\text { pandangan akan keberadaan hoax, dengan memahaminya dapat } \\
\text { berfungsi sebagai pondasi dan penyaring informasi untuk } \\
\text { memutus rantai beredarnya hoax. Hoax dibuat dengan bertujuan } \\
\text { untuk membuat opini publik, menggiring opini publik, } \\
\text { membentuk persepsi yang menguji kecerdasan dan kecermatan } \\
\text { pengguna internet dan media sosial. Informasi bohong (hoax) } \\
\text { merupakan perbuatan yang tidak baik (asubha karma) sehingga } \\
\text { dapat menjadi penyebab penderitaan, oleh karena itu dalam } \\
\text { menerima informasi hendaknya memaksimalkan wiweka untuk } \\
\text { mengkaji. Terdapat empat cara untuk mendapatkan pengetahuan } \\
\text { guna menelaah sebuah informasi yang dimuat dalam media sosial } \\
\text { untuk dapat mengetahui kebenarannya yaitu 1). Pratyaksa } \\
\text { Pramana; 2). Anumana Pramana; 3). Upamana Pramana; 4). } \\
\text { Sabda/Agama Pramana. }\end{array}$ \\
\hline $\begin{array}{l}\text { Keyword: } \\
\text { Perspective of Hindu } \\
\text { Fake news } \\
\text { Hoax }\end{array}$ & $\begin{array}{l}\text { Abstract } \\
\text { The hoax circulation is very fast because some social media users } \\
\text { share without reading or knowing more about whether it's true or } \\
\text { not. Increasing literacy can be done well if someone has adequate } \\
\text { religious knowledge. The Hinduism have a perspective the } \\
\text { existence of hoax, by understanding it can function as the basis } \\
\text { and filter of information to break the chain of hoax circulation. } \\
\text { Hoax is made with the aim of making public opinion, herding } \\
\text { public opinion, forming perceptions that tests the intelligence and } \\
\text { accuracy of internet and social media users. Fake news (hoax) is } \\
\text { an act that is not good (asubha karma) so that can be of suffering, } \\
\text { therefore in receiving information must maximize wiweka to learn. } \\
\text { There are four ways to get knowledge in order to examine an } \\
\text { information contained in social media to be able to find out the } \\
\text { truth, namely 1). Pratyaksa Pramana; 2). Anumana Pramana; } 3 \text { ). } \\
\text { Upamana Pramana; 4). Sabda/Agama Pramana. }\end{array}$ \\
\hline
\end{tabular}




\section{Pendahuluan}

Perkembangan internet dewasa ini banyak memberikan kemudahan bagi penggunanya. Informasi begitu mudah untuk didapatkan dan disebarluaskan, terlebih lagi kaum milenial, internet sudah menjadi sesuatu yang tidak asing lagi. Media sosial merupakan media memanfaatkan internet yang digunakan untuk menyampaikan pendapat, ide atau informasi. Media sosial dapat berupa facebook, whatsapp, twiter, instagram dan ada beberapa bentuk media sosial yang lainnya. Melalui media sosial berbagai macam informasi bisa diperoleh baik berupa foto, video, tulisan (artikel) maupun dalam bentuk meme. Informasi yang dimuat dapat dilihat dan dibaca oleh publik serta dapat dibagikan kembali (shared) dengan pengguna media sosial lainnya. Berbagi informasi dapat dilakukan pada media sosial yang sama misalnya facebook dengan pengguna facebook lainnya. Kemudahan lain yang diberikan yaitu berbagi antar media sosial seperti informasi di facebook dibagikan di whatsapp, instagram atau media sosial yang lainnya, sehingga penyebaran informasi akan berlangsung sangat cepat.

Mc. Luhan pernah mengemukakan bahwa kehadiran internet dewasa ini hampir mendominasi seluruh kegiatan manusia, bahkan internet bukan hanya tempat mencari informasi tetapi kini menjadi sumber pendapatan baik individu atau lembaga (Tamburaka, 2013, hal. 75). Dominasi internet dalam seluruh aspek kehidupan manusia menjadikan internet sebagai sebuah kebutuhan, mulai dari anak-anak, hingga orang dewasa dalam sehari-harinya tidak bisa lepas dengan media sosial. Berbagai informasi yang bermanfaat dapat diperoleh melalui media sosial, namun tidak jarang juga digunakan untuk menyebarkan informasi yang tidak benar (hoax).

Kemunculan media sosial bukan saja menjadi sarana yang mudah untuk menghubungkan antar manusia, namun juga mengakibatkan semakin mudah tersebarnya informasi palsu (hoax) (Juliswara, 2017, hal. 146). Informasi yang dibuat dan di unggah dalam media sosial terkadang tidak sepenuhnya benar, karena ada beberapa oknum yang memang secara sengaja untuk membuat hoax dengan tujuan tertentu, walaupun ada juga yang memberikan informasi yang benar dan sangat bermanfaat bagi pembacanya.

Data dari Kementerian Kominfo sebagaimana dikutip dari https://kominfo.go.id. peningkatan jumlah konten hoax sangat signifikan terjadi pada bulan Januari dan Februari 2019. Sebanyak 175 konten hoax yang berhasil diverifikasi oleh Tim AIS Kemkominfo. Angka ini naik dua kali lipat di Februari 2019 menjadi 353 konten hoax. Angka tersebut terus menanjak menjadi 453 hoax selama Maret 2019. Selama bulan April 2019 Kemkominfo mengidentifikasi 486 konten, jumlah tersebut merupakan terbanyak sejak Agustus 2018. Total 
jumlah hoax yang berhasil didapatkan oleh mesin AIS yang kemudian diidentifikasi, diverifikasi dan divalidasi menjadi 1.731 hoax terhitung sejak Agustus 2018 sampai dengan April 2019. Dari total 1.731 hoax kategori politik mendominasi di angka 620 item hoax. Disusul 210 hoax kategori pemerintahan, 200 hoax kategori kesehatan, 159 hoax terkait fitnah, 113 hoax terkait kejahatan dan sisanya hoax terkait isu agama, bencana alam, mitos, internasional dan isu lainnya.

Beberapa hari terakhir media sosial di hebohkan dengan hoax dalam bentuk meme yang mengatakan "Buat anggota TNI,, tunggu ya .. Sebentar lagi UU kami yang baru akan disahkan, UU Polri yang bisa menangkap langsung kamu dan memenjarakan kamu di Lapas Sipil. Terima kasih PDI dan Jokowi, kalian telah mendukung cita-cita, niat dan keinginan Polri masa kini”, (https://news.detik.com).

Memang tidak dapat dipungkiri bahwa kelebihan dari media sosial adalah dapat memberikan berbagai macam kemudahan termasuk dalam menyebarkan berita atau video, gambar maupun dokumen. Penyebran hoax disamping karena adanya kemudahan tersebut ditambah lagi dengan adanya kecenderungan masyarakat mulai berubah, yaitu selalu ingin menjadi yang pertama dalam berbagai hal termasuk dalam membagikan informasi di media sosial. Hal tersebut yang menjadikan ketika mendapatkan informasi, secara berlomba-lomba untuk membagikan tanpa membaca atau mengetahui lebih mendalam apakah itu benar atau tidak.

Kepala Biro Penerangan Masyarakat Markas Besar Kepolisian Negara Republik Indonesia Komisaris Besar Rikwanto melalui pesan pendek kepada wartawan, pada hari Minggu, 20 November 2016, sebagaimana dikutip dalam Harian online https://www.liputan6.com mengatakan bahwa "Bagi Anda yang suka mengirimkan kabar bohong (hoax), atau bahkan cuma sekadar iseng mendistribusikan (forward), harap berhatihati. Ancamannya tidak main-main, bisa kena pidana penjara enam tahun dan denda Rp 1 miliar". Lebih lanjut diungkapkan bahwa "pelaku penyebar hoax bisa terancam Pasal 28 ayat 1 Undang-Undang Informasi dan Transaksi Elektronik atau Undang-Undang ITE. Di dalam pasal itu disebutkan, "Setiap orang yang dengan sengaja dan atau tanpa hak menyebarkan berita bohong dan menyesatkan, ancamannya bisa terkena pidana maksimal enam tahun dan denda maksimal Rp 1 miliar”.

Akibat kurang cermat dalam membagikan informasi menjadikan banyak kasus yang telah diproses oleh pihak yang berwajib karena menyebarkan berita hoax. Beberapa penyebar hoax bahkan di hukum penjara karena memang terdapat aturan perundang-undangan yang mengatur 
tentang hal itu. Oknum penyebar hoax akan dikenakan penjara dan denda, walaupun hanya mendistribusikan (forward) hoax yang diterima dari orang lain. Oleh karena itu yang terkena pasal dari UU ITE bukan hanya penulis atau pembuat hoax akan tetapi juga yang menyebarkan.

Keberadaan hoax dikarenakan tidak adanya literasi, baik penulis berita di media sosial, maupun pembaca yang akan membagikan konten tersebut. Peningkatan Literasi dapat dilakukan dengan baik apabila seseorang memahami ilmu pengetahuan dan ilmu keagamaan. Ilmu pengetahuan dan agama keberadaaanya saling menopang seperti diungkapkan oleh Albert Einstein "Ilmu tanpa agama buta dan agama tanpa ilmu lumpuh". (Baunto, 2014, hal. 24) dengan ilmu hidup itu mudah, ilmu tanpa agama adalah buta, agama tanpa ilmu adalah umpuh. Ilmu pengetahuan tanpa kesadaran dapat dianalogikan ibarat orang buta, sedangkan kesadaran tanpa ilmu pengetahuan ibarat orang lumpuh. Kesadaran merupakan pengetahuan tertinggi sehingga dapat memahami dan menghayati hakekat dan realitas hidupnya sebagai mahluk ciptaan Tuhan Yang Maha Kuasa (Sukadi, 2017, hal. 19). Kesadaran yang dimaksudkan adalah penghayatan terhadap ilmu agama sebagai dasar dalam menjalani kehidupan. Ilmu dalam menggunakan internet sudah banyak dikuasai, namun pengusaan ilmu tersebut juga harus dibarengi dengan pengatahuan agama yang benar. Apabila tidak demikian maka ilmu tersebut akan dapat membawa kepada hal-hal yang tidak sesuai dengan ajaran agama.

Setiap agama tidak membenarkan kebohongan, karena kebohongan akan dapat merugikan dan menyakiti orang lain. Ajaran Agama dapat dijadikan sebagai salah satu literasi yang sangat efektif dalam mengantisipasi penulisan maupun penyebaran hoax. Beberapa ajaran dalam agama hindu dapat dijadikan sebagai literasi dalam penyebaran hoax apabila diimpementasikan dengan baik dalam kehidupan. Ajaran-ajaran tersebut perlu kiranya untuk dipahami dan diimplementasikan sehingga ketika mendapatkan sebuah informasi, dapat dilakukan penilaian dan melakukan filterisasi dengan wiweka sehingga informasi tersebut layak untuk di bagikan kembali atau tidak.

\section{Pembahasan}

\section{Hoax dan Penyebarannya}

Hoax merupakan informasi atau berita yang berisi hal-hal yang belum pasti atau yang benar-benar bukan merupakan fakta yang terjadi (Juditha, 2018, hal. 31). Hoax adalah usaha untuk menipu atau mengelabuhi/mengakali pembaca/pendengarnya sehingga mempercayai 
sesuatu, padahal sang pencipta berita palsu tersebut mengetahui bahwa berita tersebut adalah palsu (Rahadi, 2017, hal. 61).

Hoax sebagian besar dibuat dan dipahami oleh pembuatnya bahwa hal tersebut tidak benar, akan tetapi karena ingin mencapai tujuan tertentu sehingga pembuat mengabaikan aspek dampak negative dari apa yang telah dibuatnya. Hoax dibuat dengan bertujuan untuk membuat opini publik, menggiring opini publik, membentuk persepsi juga untuk having fun yang menguji kecerdasan dan kecermatan pengguna internet dan media sosial. Tujuan penyebaran hoax beragam namun beberapa disebarkan sebagai bahan lelucon atau sekedar iseng, menjatuhkan pesaing (black campaign), promosi dengan penipuan, ataupun ajakan untuk berbuat amalan-amalan baik yang sebenarnya belum ada dalil yang jelas di dalamnya. (Rahadi, 2017, hal. 61).

Kelebihan media sosial dalam menyampaikan informasi yaitu karena banyak diakses oleh berbagai kalangan. Mulai dari anak-anak, orang dewasa hingga orang tua sudah bisa menggunakan media sosial. Di sisi lain dari kemudahan yang diberikan ternyata media sosial membuka peluang besar bagi beberapa orang yang ingin menyebarkan isu-isu yang tidak benar.

Media sosial seolah-olah membawa masyarakat ke wilayah luas dan hampir tanpa batas dalam berkomunikasi. Kondisi yang tanpa tatap muka namun cepat tersaji dalam mengantarkan pesan ini kemudian berkembang pesat dan bahkan cenderung berkembang secara liar. Kondisi ini kemudian dimanfaatkan oleh sebagian orang yang kurang bertanggung jawab guna menyebarkan informasi palsu (hoax) untuk menyerang pribadi orang lain demi kepentingan diri dan atau kelompok (Juliswara, 2017, hal. 146).

Hoax dapat berawal dari isu atau informasi yang ditulis oleh oknum yang memiliki tujuan tertentu. Namun sebagian besar tujuan dari penyebaran berita bohong adalah untuk menggiring opini publik untuk mencapai tujuan dibalik dipublisnya isu-isu tersebut. Oleh karena itu setiap isu yang di unggah di media sosial sebagian besar memiliki motif tersendiri yang sengaja untuk dibuat. Ada beberapa jenis informasi hoax sebagaimana di kutip dalam (Rahadi, 2017, hal. 62) yaitu sebagai berikut :

1. Fake news: Berita bohong: berita yang berusaha menggantikan berita yang asli. Berita ini bertujuan untuk memalsukan atau memasukkan ketidakbenaran dalam suatu berita.

2. Clickbait: Tautan jebakan: Tautan yang diletakkan secara stategis di dalam suatu situs dengan tujuan untuk menarik orang masuk ke situs lainnya. Konten di dalam tautan ini sesuai fakta namun judulnya dibuat berlebihan atau dipasang gambar yang menarik untuk memancing pembaca. 
3. Confirmation bias : Bias konfirmasi: Kecenderungan untuk menginterpretasikan kejadian yang baru terjadi sebagai bukti dari kepercayaan yang sudah ada.

4. Misinformation: Informasi yang salah atau tidak akurat, terutama yang ditujukan untuk menipu.

5. Satire: Sebuah tulisan yang menggunakan humor, ironi, hal yang dibesar-besarkan untuk mengkomentari kejadian yang sedang hangat.

6. Post-truth: Pasca-kebenaran: Kejadian di mana emosi lebih berperan daripada fakta untuk membentuk opini publik.

7. Propaganda: Aktifitas menyebar luaskan informasi, fakta, argumen, gosip, setengahkebenaran, atau bahkan kebohongan untuk mempengaruhi opini publik.

Beberapa isu yang ditulis awalnya tanpa memiliki tujuan, dengan maksud ditulis hanya untuk sekedar iseng saja. Namun lambat laun tidak menutup kemungkinan isu tersebut memiliki tujuan karena ditumpangi oleh beberapa orang yang memiliki kepentingan karena dianggap sesuai dengan isu yang dibuat. Sehingga dari beberapa kasus penulis hoax tidak menyadari bahwa tulisannya tersebut akan dapat memiliki dampak besar, bahkan sampai merugikan orang lain.

Isu atau informasi dengan media sosial begitu cepat beredar, begitu banyak media sosial yang bisa digunakan sebagai tempat untuk menulis atau menyebarkan informasi. Seperti Facebook, whatsapp, instagram, telegram, skype dan beberapa media sosial lainnya merupakan media yang banyak digunakan mulai dari anak-anak hingga orang tua. Media sosial inilah yang banyak dimanfaatkan untuk menyebarluaskan hoax dengan tujuan yang beraneka ragam.

Beberapa kemudahan lain yang ditawarkan dari media sosial adalah user dapat dengan mudah untuk membagikan (forward) informasi yang di terimanya. Hal tersebut akan memberikan banyak manfaat apabila informasi yang di bagikan adalah informasi yang benar dan memiliki manfaat bagi user lainnya. Akan tetapi akan berakibat fatal apabila informasi yang dibagikan ternyata adalah berita yang tidak benar (hoax). Berita tersebut akan menyebar sangat cepat, dan hanya dengan hitungan detik sudah bisa menyebar keseluruh belahan dunia.

Penyebaran hoax dapat terjadi karena user hanya membaca sekilas, atau hanya membaca judul dari berita/informasi yang diterimanya. User tidak membaca isi atau tidak memahami lebih mendalam isi dari informasi tersebut. Setelah dipahami tentu perlu untuk mempertimbangkan secara matang apakah hal itu baik untuk orang lain dengan batasan usia 
tertentu. Budaya untuk membaca dan memahami secara lebih mendalam merupakan langkah pertama yang harus dilakukan oleh user sebelum membagikan informasi kepada orang lain.

Disamping kurangnya membaca, memahami dan mengkaji data dari informasi yang disajikan, penyebaran hoax juga dapat disebabkan oleh kurangnya pemahaman akan aturan terkait dengan penyebaran berita bohong. User tidak menyadari bahwa apabila berita bohong di bagikan kembali, secara hukum yang bersalah adalah user tersebut, bukan hanya penulis.

Sifat ingin menjadi yang utama dan pertama juga menjadi salah satu pemuicu cepatnya beredar berita hoax di media sosial. Beberapa user kurang memikirkan dampak dari apa yang dia sebarkan, hanya berpikir bahwa, bagaimana cara agar menjadi orang yang pertama atau lebih awal dari yang lainnya untuk membagikan informasi. Hanya ingin mendapatkan pengakuan dari publik sebagai orang yang paling cepat membagikan informasi, sehingga akan sangat terburu-buru tanpa membaca, apalagi memahami dan meneliti data yang ada dalam informasi tersebut.

\section{Hoax dalam Perspektif Agama Hindu}

Setiap manusia menginginkan kebahagiaan dalam kehidupnya. Kebahagiaan mutlak dalam ajaran agama Hindu yaitu apabila bersatunya Atman dengan Jiwatman. Atman sebagai jiwa/roh yang ada dalam diri sedangkan Jiwatman adalah Brahman. Bersatunya Atman dengan Brahman sangat ditentukan oleh karma masing-masing individu, karena manusia tidak bisa terlepas dari hukum karma. Bhagavadgita menyebutkan bahwa sebagai berikut :

na karmaṇām anārambhān

naișkarmyaḿ puruṣo 'śnute

na ca sannyāsanād eva

siddhiḿ samadhigacchati

(B.G. III.4)

Artinya :

Seseorang tidak dapat melampaui (hukum) karma dengan cara tidak bertindak; ia tidak dapat meraih kesempurnaan lewat pelepasan diri dari segala tindakan (https://bhagavadgita.or.id).

Seseorang akan dapat mencapai kesempurnaan dan kelepasan dengan melakukan kerja (karma). Setiap saat seseorang melakukan karma, tidak seorangpun dapat terlepas dari karma, yang membedakan adalah apakah karma baik atau karma buruk yang diperbuatnya. Apabila perbuatannya baik (subha karma) berbarti telah melakukan karma baik dan tentu akan 
mendapatkan hasil yang baik, demikian sebaliknya apabila perbuatan tidak baik (asubha Karma) yang diperbuat maka akan mendapatkan hasil yang buruk. Sesungguhnya Karma bersumber dari pikiran (manacika), perkataan (wacika) dan perbuatan (kayika). Ketiga hal tersebut sebaiknya di jaga dan di arahkan sehingga tidak menjadi penyebab penderitaan dalam kehidupannya.

Berita bohong (hoax) merupakan perbuatan yang tidak baik (asubha karma) sehingga hal tersebut akan menghasilkan karma buruk dan dapat menjadi penyebab penderitaan bagi pelakunya. Pembuat berita tidak benar bukan berarti tidak memiliki ilmu pengetahuan, akan tetapi pengetahuan yang dimiliki di pergunakan untuk hal yang negatif. Seseorang yang mampu untuk membuat berita, apalagi mampu mempengaruhi orang lain dengan tulisannya sesungguhnya merupakan orang yang memiliki pengetahuan yang cukup matang. Ilmu pengetahuan yang dimiliki tidak di manfaatkan untuk kebaikan akan tetapi diarahkan untuk hal yang bersifat negatif.

https://student.cnnindonesia.com menyebutkan bahwa ada segelintir orang yang mempunyai ilmu pengetahuan yang lebih dari pada orang lain namun digunakan untuk menghasut dan menipu, mencoba menakut-nakuti agar tidak percaya pada pihak tertentu. Adapula yang berusaha meyakinkan banyak orang lewat tulisan yang menjadi informasi bagi orang lain, yang bukan untuk menambah ilmu pengetahuan bagi orang lain namun yang terjadi adalah menumbuhkan rasa resah yang berujung pada rasa curiga dan saling tuding. Oleh karena itu akibatnya banyak yang terhasut atas apa yang di sampaikan oleh oknum tersebut sehingga membuat situasi semakin gaduh. Selain itu yang terjadi adalah masyarakat menjadi bingung dan bukan tidak mungkin terjadi adu domba diantara masyarakat yang diprovokasi oleh pesanpesan yang disampaikan oleh oknum yang seharusnya dapat menyebarkan ilmu pengetahuan yang lebih baik dan bermanfaat.

Hal inilah yang dilakukan oleh para pembuat berita bohong dengan ilmu pengetahuan yang dimiliki. Pengetahuan pada dasarnya digunakan untuk hal yang baik secara benar dan dapat bermanfaat untuk diri sendiri serta orang lain. Manfaat pengetahuan sebagaimana dimuat dalam kitab Bhagavad Gita mengungkapkan sebagai berikut :
api ced asi papebhyah
sarvebhyah papa-krt-tamah
sarvam jnana-plavenaiva
vrjinam santarisyasi

(BG. IV.36) 
Artinya :

Walaupun seandainya engkau paling berdosa di antara manusia yang memikul dosa, dengan perahu ilmu pengetahuan lautan dosa akan engkau seberangi (Pudja, Bhagavad Gita, 2004, hal. 127).

Sloka di atas mengungkapkan bahwa pengetahuan itu sangatlah bermanfaat karena walaupun termasuk dalam orang yang paling berdosa, dengan ilmu pengetahuan yang dimiliki akan dapat membantu untuk mencapai kedamaian. Hal tersebut akan dapat dicapai apabila pengetahuan yang dimiliki senantiasa di gunakan untuk kebajikan. Pembuat hoax seharusnya menggunakan pengetahuan yang dimiliki untuk menulis hal-hal yang baik, membuat kontenkonten yang positif, dan menyebarkan kedamaian dalam kehidupan bermasyarakat berbangsa dan bernegara. Dengan demikian pengetahuan yang dimiliki akan bermanfaat bagi orang lain.

Para produksi hoax memiliki niat untuk membohongi orang lain, atau mengelabuhi orang lain yang kurang teliti dalam menerima informasi. Tulisannya atau informasi yang dibuat tidak mencerminkan sesuatu yang benar-benar terjadi atau kadangkala tidak jujur dalam menyampaikan informasi. Orang yang membuat berita bohong (hoax) akan mendapatkan penderitaan sebagaimana diungkapkan dalam kitab Sarasamusscaya 131 sebagai berikut :

Hana tang wang ujar makaphala laraning para, umakusara siddha ning karyaning kunang, ndan mithya ya, ikang wwang mangkana kramanya, tan atakut ring naraka ika, ta karin pagawayaken awaknya kapapan ngaranika, apan ikang para prasiddhaning mukti kapapanya, sangksepanika, tan ujarakenang ujar mangkana. Artinya :

Adalah orang yang berkata, yang mengakibatkan kesedihan orang lain, entahlah menyanggupi atas selesainya kerja orang lain, akan tetapi ternyata ia berbohong; orang yang demikian perilakunya tidak takut akan kawah neraka; bukanlah ia berbuat celaka bagi dirinya sendiri, sekalipun orang lain sebenarnya yang mengalami malapetaka itu; singkatnya, janganlah mengucapkan perkataan yang demikian itu (Kajeng, 2010, hal. 111).

Sloka di atas mengungkapkan bahwa ketika seseorang berbohong atau berkata yang mengakibatkan kesedihan kepada orang lain, dianggap sebagai orang yang tidak takut akan neraka. Ini mengisyaratkan bahwa, ketika membuat kebohongan maka akan mendapatkan kesengsaraan berupa neraka. Oleh karena itu hendaknya jangan berkata bohong dan selalu menyampaikan kejujuran dan kebenaran. 
Kejujuran biasa diistilahkan dengan kata dalam bahasa sansekerta Satya dari urat kata "Sat" yang berarti Kebenaran, kejujuran, Tuhan (ketuhanan). Dengan demikian Satya dapat berarti kebenaran yaitu merupakan sifat hakikat dari Tuhan Yang Maha Esa, dan dapat pula diartikan kesetiaan atau kejujuran. Kejujuran merupakan penopang dalam dalam pencapaian kebahagiaan, kitab Manawa Dharma Sastra mengungkapkan sebagai berikut :

Satyam saksya bruvam

saksi lokanproti puskalan,

iha canuttamam kirtim

vagesa brahmapujita

(M.D.S. VIII.81)

Artinya :

Seorang saksi yang mengatakan kebenaran dalam kesaksiannya, memperoleh tempat yang terindah sebagai rahmat setelah meninggal dan disini memperoleh nama baik yang tak terlebihi, pembuktian seperti dihormati oleh brahmana itu sendiri (Pudja \& Sudharta, Manawadharmasastra (Manu Dharmasastra), 2002, hal. 436).

Kutipan di atas menyiratkan bahwa kebahagiaan yang terindah akan diperoleh bagi orang-orang yang mengatakan kebenaran. Bukan hanya mendapatkan kebahagiaan namun akan selalu dihargai oleh orang lain serta ketika meninggal kelak atmannya akan diterima oleh para dewa dan diantar kealam sorga yang penuh dengan keindahan. Terkait dengan kejujuran dalam Sarasamuccaya juga diungkapkan seperti berikut:

Kuneng lwir ingujarakena nihan, satya ta ya, makawak hingsa,

haywa makawak upet, hitawasana ta ya,

haywa ta parusya, haywa kasletan gleng,

haywa pesunya, mangkana twirning tan yogya ujarakena.

(Ss. 132)

Artinya :

Adapun kata-kata yang patut diucapkan, ialah kata-kata yang mengandung kebenaran (kejujuran); jangan yang berupa penusuk hati, jangan yang merupakan umpatan, hendaklah kata-kata yang bermanfaat, janganlah kata-kata yang kasar, jangan kata-kata yang terpengaruhi kemarahan, jangan kata-kata mementingkan diri sendiri, jangan katakata fitnahan; demikianlah misalnya kata-kata yang tidak dikeluarkan (Kajeng, 2010, hal. 112). 
Informasi yang diberikan melalui media sosial hendaknya merupakan informasi yang benar, karena informasi tersebut merupakan ungkapan kata-kata yang tuangkan dalam bentuk berita atau artikel maupun informasi lainnya. Oleh karena itu hal tersebut harus merupakan kebenaran, bukan merupakan informasi yang dapat membuat orang lain sakit hati ketika membacanya. Sloka di atas juga menyiratkan bahwa hendaknya apa yang disampaikan bukan merupakan informasi yang dapat menimbulkan provokasi dan fitnah.

Kejujuran dalam menyampaikan informasi juga terjadi dalam masa perang Bharatayuda dalam Mahabharata, diceritakan bahwa pada hari kelima belas merupakan perang yang paling menakutkan, karena Drona telah kehilangan semua dharma yang dimilikinya. Drona mengeluarkan astranya, dua ribu orang mati dalam sekejap karena brahmastra yang dihujamkan kepada para prajurit pandawa. Kresna melihat ketakutan dalam pasukan pandawa dan berkata "Yudhistira, orang ini tidak bisa dikalahkan dalam peperangan, jika dibiarkan engkau hanya akan memiliki seorang prajurit yang masih hidup saat malam tiba, Drona hanya akan menyerah dan tidak mau bertarung jika mengetahui anaknya Asvatthama telah tewas". Kemudian bhima menuju ke tengah-tengah pasukannya dengan gadanya dan membunuh gajah raja Melava yang bernama Asvatthama. Bhima kemudian menghampiri Drona dan berkata "Asvatthama telah tewas". Mendengar hal tersebut Drona sangat kecewa dan tidak bersemangat lagi, kemudian bertanya kepada Yudhistira sebagai orang yang sangat dipercayainya dan berkata "anakku, aku ingin kau memberitahukan kepadaku apakah benar anakku telah mati?" Yudhistira berkata "Asvattama telah tewas", dengan berlahan ia menambahan "gajah yang bernama Asvattama" (Subramaniam, 2003, hal. 652-657).

Kutipan cerita Mahabharata tersebut menceritakan bagaimana dalam situasi apapun tetap untuk menyampaikan kebenaran. Apa yang telah dikatakan oleh Yudhistira memanglah kebenaran, karena ia mengatakan bahwa Asvattama telah tewas, gajah yang bernama Asvattama. Hanya saja karena pada saat itu dalam keadaan perang, sehingga suara gemuruh dan dan suasana sangat bising menjadikan Drona tidak mendengar dengan jelas bahwa yang tewas itu adalah gajah yang bernama Asvattama.

Hoax menyebar dengan sangat cepat di media sosial dipengaruhi oleh banyaknya orangorang yang membagikan berita bohong tersebut. Beberapa orang membagikan informasi yang diterima tanpa mengkaji terlebih dahulu tentang kebenarannya dan langsung membagikannya. Bahkan beberapa orang yang menerima informasi tanpa membaca isi informasi hanya dengan membaca judul saja kemudian membagikannya. Kurangnya budaya membaca dan memahami 
serta mencari tahu kebenaran informasi yang diterima menjadikan penyebaran berita bohong (hoax) tersebar dengan sangat cepat.

Seseorang dalam menerima informasi hendaknya tidak bergitu saja langsung percaya dan membagikan informasi yang diperoleh melalui media sosial. Manusia dalam konsep hindu memiliki kelebihan dibandingkan ciptaan tuhan lainnya. Manusia merupakan mahluk yang paling istimewa sebagaimana di ungkapkan dalam kitab Sarasamusccaya sebagai berikut :

Apan iking dadi wwang, uttama juga ya, nimittaning mangkana,

wenang ya tumulung awaknya sangkeng sangsara,

maka sadhanang subha karma hinganing

kottamaning dadi wwang ika

(Ss. 4)

Artinya :

Menjelma menjadi manusia itu adalah sungguh-sungguh utama; sebabnya demikian, karena ia dapat menolong dirinya dari keadaan sengsara dengan jalan berbuat baik; demikianlah keuntungannya dapat menjelma menjadi manusia (Kajeng, 2010, hal.9) Sebelumnya pada sarasamusscaya sloka 2 dituliskan bahwa,

Risakwehning sarwa bhuta, iking janma

wwang juga wenang gumawayaken ikang subhasubha karma,

kuneng panentasakna ring subhakarma juga ikangasubhakarma,

phalaning dadi wwang.

Artinya :

Diantara semua makhluk hidup, hanya yang dilahirkan menjadi manusia sajalah, yang dapat melakukan perbuatan baik atau perbuatan buruk, leburlah kedalam perbuatan baik, segala perbuatan yang buruk itu; demikianlah gunanya (pahalanya) menjadi manusia (Kajeng, 2010, hal. 7)

Kutipan sloka di atas mengungkapkan bahwa bersyukurlah di lahirkan sebagai manusia karena dapat menolong dirinya sendiri, dengan selalu berbuat baik sehingga akan mendapatkan karma yang baik. Manusia harus mampu memaksimalkan kelebihan tersebut sebagai usaha untuk meningkatkan kualitas kehidupan dan melepaskan diri dari samsara/punarbhawa. Karma wasana yang timbul akibat dari apa yang dilakukan pada kehidupan ini akan memiliki pengaruh terhadap kehidupan yang sekarang maupun akan datang. 
Penyebar hoax dalam hal ini juga harus menyadari akan kelebihan yang dimiliki sebagai manusia, dengan demikian akan dapat memberikan informasi yang benar dan bermanfaat bagi masyarakat. Walaupun menerima informasi yang tidak benar, sebagai manusia yang mampu membedakan mana yang baik dan yang buruk hendaknya tidak menyebarkan kembali dan akan lebih baik apabila mampu menginformasikan kepada pengguna media sosial yang lain tentang ketidakbenaran informasi tersebut.

Informasi yang diterima hendaknya dipilah-pilah dengan menggunakan Wiweka yang dimiliki. Wiweka merupakan kemampuan manusia untuk memilah mana yang baik yang patut untuk dilakukan dan mana yang buruk untuk dihindari. Kemampuan memilah akan dilakukan oleh pikiran, karena pikiranlah yang menjadi awal dari perkataan maupun perbuatan yang dilakukan oleh manusia. Dalam kitab suci Sarasamuccaya 80 dikatakan bahwa:

Apan ikang manah ngaranya, ya ika witning indriya, maprewertti ta ya ring cubha acubha karma, matangnyan ikang manah juge prihen kahrtanya sekareng

(Ss. 80)

Artinya:

Sebab yang disebut pikiran itu, adalah sumbernya nafsu, ialah yang menggerakan perbuatan yang baik ataupun yang buruk; oleh karena itu pikiranlah yang segera patut diusahakan pengekangannya (Kajeng, 2010, hal. 70).

Para pengguna media sosial hendaknya dapat mengendalikan pikirannya, karena jika pikiran dapat dikendalikan maka ketika mendapat informasi, akan memikirkan apakah informasi itu benar dan layak untuk di bagikan atau tidak perlu di bagikan kembali. Selain itu juga harus mampu untuk mengendalikan ego, karena beberapa orang yang membagikan informasi dilakukan hanya karena agar terlihat menjadi orang yang paling cepat dalam berbagi informasi. sehingga begitu mendapat informasi yang dianggap menarik tanpa berpikir panjang dibagikan, sehingga hanya dalam hitungan detik informasi itu sudah sampai kepengguna media sosial lainnya.

Agama hindu mengajarkan pramana yaitu cara untuk mengetahui sesuatu dengan sebenarnya (Pendit, 2007, hal. 11). Lontar Wrhaspati Tattwa 26 menguraikan ada tiga cara yang digunakan untuk mendapatkan pengetahuan "Pratyaksanumanasca krtan tad wacanagamah pramananitriwidamproktam tat samyajnanam uttamam. Ikang sang kahanan dening pramana telu, ngaranya, pratyaksanumanagama (Suhardana, 2010, hal. 93). Artinya 
adapun orang yang dikatakan memiliki tiga cara untuk mendapat pengetahuan yang disebut Pratyaksa, Anumana, dan Agama.

Sistem filsafat Nyaya yang didirikan oleh Rsi Gautama mengatakan bahwa ada 4 cara memperoleh pengetahuan yaitu perspesi atau pengamatan (Pratyaksa), menarik kesimpulan (Anumana), perbandingan (Upamana), dan penyaksian kata-kata atau melalui perkataan (Sabda) (Sivananda, 2003, hal. 180).

Dari kutipan di atas apabila digabungkan antara yang termuat dalam lontar Wrhaspati Tattwa dan dalam sistem filsafat Nyaya terdapat empat cara yang bisa dijadikan pedoman dalam mendapatkan pengetahuan. Keempat cara sebagaimana diungkapkan tersebut dapat dijadikan sebagai literasi sehingga dapat memastikan apakah informasi yang ada di media sosial tersebut benar atau merupakan informasi yang tidak benar (hoax). Oleh karena itu dalam konteks literasi hoax maka keempat bagian tersebut dapat digunakan baik secara bersamaan maupun masing-masing. Keempat cara tersebut dapat diuraikan sebagai berikut :

\section{Pratyaksa Pramana}

Pratyaksa pramana yaitu cara untuk mendapatkan pengetahuan dengan cara mengadakan pengamatan. "Pratyaksa ngaranya katon kagamel”" (Suhardana, 2010, hal. 93). Pratyaksa adalah sesuatu yang dapat di lihat dan sesuatu yang dapat dipegang. (Pendit, 2007, hal. 11-15) Pratyaksa disamakan dengan persepsi yang merupakan suatu pengetahuan yang pasti diciptakan oleh hubungan indera-objek. Memanfaatkan pengelihatan atau pengamatan untuk mendapatkan sebuah kebenaran, hal tersebut bisa digunakan dalam meliterasi informasi yang beredar di media sosial.

Persepsi di klasifikasikan menjadi dua, pertama yaitu persepsi biasa (laukika) merupakan persepsi yang apabila ada hubungan indera yang biasa dengan objek-objek yang dihadapkan kepada indera. Kedua yaitu persepsi luar biasa (alaukika) apabila objek tidak secara biasa dihadapkan kepada indera melainkan disampaikan kepada indera melalui media yang biasa (Pendit, 2007, hal. 17).

Kebenaran informasi yang diterima hendaknya dikaji lebih mendalam melalui pengamatan panca indera. Pengamatan secara seksama dan detail sebuah informasi yang diterima akan dapat diketahui informasi tersebut baik atau tidak bagi pembaca lainnya. Persepsi biasa (laukika) mempunyai enam macam bagian yaitu pengelihatan (Caksusa), pendengaran (Srautra), rabaan atau sentuhan (Sparsana), rasa, selera (Rasana), penciuman (Ghranaja) dan internal atau mental (Manasa), (Pandit, 2007:17). 
Melakukan identifikasi terhadap sebuah informasi dalam media sosial dilakukan dengan mempersepsikan kontens yang terdapat di dalamnya. Oleh karena itu persepsi biasa (laukika) yang dominan digunakan yaitu pengelihatan (caksusa) apabila informasi tersebut berbentuk visual namun tidak memiliki audio. Pengunaan pendengaran (srautra) digunakan apabila informasi yang dimuat memiliki efek audio. Indentifikasi terhadap kebenaran informasi yang disebar melalui media sosial juga dapat dilakukan dengan menggunakan keduanya laukika secara bersamaan, disesuaikan dengan bagian dari konten informasi yang dapat di persepsikan.

Hal yang dapat diamati pada informasi di media sosial diantaranya apabila dalam bentuk website, maka bisa dilihat pemilik web, kemudian kontak yang dicantumkan tidak dapat dihubungi. Jika informasi berupa berita tentu harus melihat struktur tata bahasa, tanggal kejadian tidak jelas, bahasa memuat provokasi dan hal lain yang biasanya terlihat tidak seperti biasanya. Postingan berupa foto atau meme dapat terlihat jelas biasanya dari editan foto yang mungkin masih ada bagian yang tidak teredit dengan baik. Postingan yang memperlihatkan video dengan suara (audio) dapat dilakukan dengan memperhatikan kesesuaian antara gerakan bibir dengan suara yang di hasilkan serta posisi gambar dengan suara yang dihasilkan. Hal-hal yang lain juga perlu dilakukan pengamatan lebih detail hingga benar-benar yakin bahwa itu merupakan sebuah kebenaran.

\section{Anumana Pramana}

Anumana Pramana yaitu cara untuk mendapatkan pengetahuan dengan melihat gejalagejala yang ada kemudian membuat suatu kesimpulan. (Pendit, 2007, hal. 11) Anumana merupakan kesimpulan, (Suhardana, 2010, hal. 94) Anumana ngaranya kadyangganing anon kukus ring kadohan, yata manganuhingganing apuy, yeka Anumana ngaranya artinya Anumana sebutannya sebagai melihat asap di tempat jauh, untuk membuktikan kepastian (adanya) api, itulah disebut Anumana .

Pada konteks litersi berita bohong yang banyak beredar di media sosial, maka Anumana pramana sangat dibutuhkan. Setelah dilakukan pengamatan maka perlu juga dilakukan pengkajian sebab akibat. Sesuatu yang terjadi pasti memiliki sebab, karena pada sesungguhnya sesuai dengan konsep keyakinan segala sesuatu yang terjadi adalah merupakan akibat dari sesuatu yang terjadi sebelumnya, atau sesuatu yang dilakukan akan memberika akibat dikemudian hari. Seperti ungkapan yang mengatakan "yatra yatra dhumah, tatra tatra wahnih" yang artinya di mana ada asap di sana pasti ada api. 
Krishna dalam https://wikakrishna.wordpress.com menyebutkan bawah proses penyimpulan melalui beberapa tahapan yaitu :

1. Pratijna yaitu memperkenalkan objek permasalahan tentang kebenaran pegamatan.

2. Hetu yaitu alasan penyimpulan.

3. Udaharana yaitu menghubungkan dengan aturan umum itu dengan suatu masalah.

4. Upayana yaitu pemakaian aturan umum pada kenyataan yang dilihat.

5. Nigamaya yaitu penyimpulan yang benar dan pasti dari proses sebelumnya.

Isi informasi yang ada dalam sosial media, hendaknya dikaji kronologis kejadiannya jika itu merupakan informasi terkait sebuah kejadian. Membuat kesimpulan diarahkan terhadap berita benar atau tidak terkait objek dari informasi yang diberikan. Langkah berikutnya adalah mengkaitkan antara informasi dengan keadaan informasi yang sejenis pada umumnya. Setelah hal tersebut dilakukan kemudian memasukan informasi tersebut pada aturan-aturan yang ada dalam masyarakat, bisa berupa undang-undang atau aturan lainnya. Langkah terakhir dari proses tersebut adalah mengambil sebuah keputusan terkait kebenaran informasi tersebut.

Apabila setelah dikaji kemudian secara logika hal itu bisa saja terjadi maka besar kemungkinan informasi tersebut adalah sebuah kebenaran. Sangat penting untuk mengkaji gejala-gejala yang ada baik ketika informasi itu di terima maupun kejadian atau hal-hal yang terjadi sebelumnya perlu dirunut hingga munculnya informasi tersebut. Hal tersebut sebagai bahan pertimbangan dalam menganalisis informasi yang diterima.

\section{Upamana Pramana}

Upamana yaitu memperoleh pengetahuan melalui persamaan atau perbandingan (Pendit, 2007, hal. 11). Perbandingan dilakukan untuk menganalisis apakah informasi yang disajikan dalam media sosial tersebut benar atau tidak. Dalam pelaksanaannya upamana pramana dilakukan dengan membandingkan antar informasi yang satu dengan informasi lainnya.

Informasi yang ada perlu dikaji pada sumber lain, dan mencocokan informasi tersebut. Perbedaan informasi yang ada, memberi indikasi adanya ketidakbenaran dalam salah satu informasi yang di bandingkan. Pembandingan perlu dilakukan secara detail dari item-item yang ada, sehingga tidak ada bagian yang terlewatkan. Informasi yang sama dalam media yang berbeda, dan oleh sumber yang berbeda bisa menjadi sebuah pedoman untuk menentukan informasi yang ada tersebut benar adanya.

Selain dengan membandingkan informasi dari satu website dengan website lainnya atau dari penulis dengan penulis informasi lainnya biasanya yang berbentuk berita. Pengecekan 
kebenaran akan informasi yang dimuat dalam media sosial juga dapat dilakukan dengan mencari informasi dengan pembaca lainnya. Pencarian informasi dengan pembaca lainnya dapat dilakukan dengan bertanya secara langsung terkait dengan kebenaran informasi yang sama-sama diperolehnya. Kesamaan persepsi antara pembaca bisa meminimalisir kelalaian dalam mengidentifikasi informasi sehingga menimalisir penyebaran informasi bohong.

\section{Sabda/Agama Pramana}

Agama Pramana yaitu cara untuk mendapatkan pengetahuan dengan cara mempelajari kitab suci dan mendengarkan petunjuk-petunjuk dari orang yang dapat dipercaya kebenarannya. (Pendit, 2007, hal. 11) mengungkapkan bahwa Sabda Pramana yaitu penyaksian kata-kata atau melalui perkataan. Pengetahuan diperoleh melalui kesaksian orang yang mempunyai sesuatu terkait dengan sesuatu. Weda merupakan kesaksian yang dipercaya sebagai sumber dari ilmu pengetahuan. Hal-hal yang termuat dalam weda merupakan suatu kebenaran yang dapat dipercaya.

Sabda/Agama Pramana digunakan untuk mendapatkan pengetahuan yang benar. Informasi yang diterima melalui sosial media dikaji dengan menggunakan filsafat agama yaitu kebenaran, karena pada dasarnya semua agama mengajarkan akan kebenaran. Isi informasi yang diterima dikaji dengan ukuran dharma, etika dan tata susila. Apabila informasi itu baik mengandung kebenaran (dharma) dengan cara pandang agama, maka informasi tersebut akan bermanfaat bagi orang lain. Demikian sebaliknya apabila secara sudut pandang agama informasi itu tidak baik (adharma), maka itu akan berdampak tidak baik bagi pembacanya.

Informasi yang diterima perlu dikaji secara etika, apabila cara dalam penyampaian atau menuangkan informasi tidak memperhatikan etika maka informasi tersebut bisa diindikasikan sebagai hoax. Penyampaian informasi yang benar akan selalu mempertimbangkan etika dan tata susila, karena menginginkan pembaca merasa nyaman untuk membaca informasi yang disajikan. Misalnya informasi yang menyudutkan salah satu pihak, atau memiliki unsur sara, menjelekkan salah satu keyakinan dan informasi-informasi yang lainnya yang mengarah pada informasi yang sifatnya tidak mendidik.

Kesaksian sebagaimana dimuat dalam http://wikakrishna.wordpress.com terdiri dari 2 jenis yaitu sebagai berikut :

1. Laukika Sabda yaitu kesaksian yang didapat dari orang-orang terpercaya dan kesaksiannya dapat diterima akal sehat,

2. Vaidika Sabda yaitu kesaksian yang didasarkan pada naskah-naskah suci weda. 
Penggunaan kesaksian dari orang-orang terpercaya dan kitab suci weda juga dapat digunakan sebagai bahan pertimbangan dalam menilai sebuah informasi yang di muat dalam media sosial. Pendapat orang-orang yang memahami ilmu agama seperti para pinandita dan para pandita dapat dijadikan bahan pertimbangan menilai sebuah informasi. Para pemuka agama dianggap sebagai orang yang banyak memahami tentang ajaran agama, dan patut untuk dijadikan panutan sepanjang hal tersebut sesuai dengan logika. Mantra-mantra yang terdapat dalam kitab suci weda terkait dengan informasi yang di kaji, akan sangat berperan dalam menyeleksi sebuah informasi, karena dalam kitab weda merupakan sumber ilmu pengetahuan yang diakui kebenarannya.

\section{Simpulan}

Informasi yang dibuat dan di unggah dalam media sosial terkadang tidak sepenuhnya benar, karena ada beberapa oknum yang memang secara sengaja untuk membuat berita hoax dengan tujuan tertentu. Peredaran hoax sangat cepat karena beberapa pengguna media sosial membagikan tanpa membaca atau mengetahui lebih mendalam apakah itu benar atau tidak. Peningkatan Literasi dapat dilakukan dengan dengan baik apabila seseorang memiliki pengetahuan keagamaan yang memadai. Agama Hindu memiliki pandangan akan keberadaan hoax, dengan memahaminya dapat berfungsi sebagai pondasi dan penyaring informasi untuk memutus rantai beredarnya hoax.

Hoax dibuat dengan bertujuan untuk membuat opini publik, menggiring opini publik, membentuk persepsi yang menguji kecerdasan dan kecermatan pengguna internet dan media sosial. Hoax dapat berawal dari isu atau informasi yang ditulis oleh untuk menggiring opini publik. Kemudahan lain yang ditawarkan dari media sosial adalah user dapat dengan mudah untuk membagikan (shared) informasi yang di terimanya. Berita bohong (hoax) merupakan perbuatan yang tidak baik (asubha karma) sehingga hal tersebut akan menghasilkan karma buruk dan dapat menjadi penyebab penderitaan bagi pelakunya. Pengetahuan pada dasarnya digunakan untuk hal yang baik secara benar dan dapat bermanfaat untuk diri sendiri serta orang lain. Apabila salah digunakan maka akan menjadi penyebab penderitaan, oleh karena itu dalam menerima informasi hendaknya memaksimalkan wiweka untuk mengkaji. Terdapat empat cara untuk mendapatkan pengetahuan sesuai dengan yang tertuang dalam sistem filsafat nyaya. Ketiga hal tersebut juga dapat digunakan untuk menelaah sebuah informasi yang dimuat dalam media sosial untuk dapat mengetahui kebenarannya.

1. Pratyaksa Pramana yaitu cara untuk mendapatkan pengetahuan dengan cara mengadakan pengamatan.

Satya Widya: Jurnal Studi Agama

Volume 2 Nomor 1 Juni 2019 
2. Anumana Pramana yaitu cara untuk mendapatkan pengetahuan dengan melihat gejalagejala yang ada.

3. Upamana Pramana yaitu memperoleh pengetahuan melalui persamaan atau perbandingan

4. Sabda/Agama Pramana yaitu cara untuk mendapatkan pengetahuan dengan cara mempelajari kitab suci dan mendengarkan petunjuk-petunjuk dari orang yang dapat dipercaya kebenarannya. Isi informasi yang diterima dikaji dengan ukuran dharma, etika, dan tata susila.

\section{Daftar Pustaka}

Baunto, L. M. (2014). Perspektif Agama dan Kebudayaan Dalam Kehidupan Masyarakat Indonesia (Suatu Tinjauan Sosiologi Agama). Jurnal Pendidikan Ilmu Sosial Vo. 23, No. 2, 11-25.

Juditha, C. (2018). Interaksi Komunikasi Hoax di Media Sosial Serta Implikasinya. Jurna Pekomnas Vol. 3, No. 1, 31-44.

Juliswara, V. (2017). Mengembangkan Model Literasi Media Yang Berkebhinekaan dalam Menganalisis Informasi Berita Palsu (hoax) di Media Sosial. Jurnal Pemikiran Sosiologi Vol. 4 No. 2 , 142-164.

Kajeng, I. N. (2010). Sarasamuccaya. Surabaya: Paramita.

Pendit, N. S. (2007). Filsafat Hindu Dharma Sad-Darsana. Denpasar: PT. Offset BP.

Pudja, G. (2004). Bhagavad Gita. Surabaya: Paramita.

Pudja, G., \& Sudharta, T. R. (2002). Manawadharmasastra (Manu Dharmasastra). Jakarta: CV. Pelita Nusantara Lestari.

Rahadi, D. R. (2017). Perilaku Pengguna dan Informasi Hoax di Media Sosial. Jurnal Manajemen dan Kewirausahaan Vol. 5, No. 1, 58-70.

Sivananda, S. S. (2003). Intisari Ajaran Hindu. Surabaya: Paramita.

Subramaniam, K. (2003). Mahabharata. Surabaya: Paramita.

Suhardana, K. (2010). Wrhaspati Tattaw Sebagai Filsafat Agama Hindu. Surabaya: Paramita.

Sukadi. (2017). Pengetahuan Menurut Hindu dan Implikasinya Terhadap Pendidikan Manusia Seutuhnya . Jurnal Purwadita Vol. 1, No. 1, 19-26.

Tamburaka, A. (2013). Literasi Media. Cerdas Bermedia Khalayak Media Massa. Jakarta: Rajawali Pers.

https://bhagavadgita.or.id/percakapan-3/. Akses pada tanggal 25 juni 2019

Satya Widya: Jurnal Studi Agama

Volume 2 Nomor 1 Juni 2019 
https://student.cnnindonesia.com. Akses pada tanggal 15 juni 2019

Krishna, Ida Bagus Wika. (2016). Hindu 4 Pengamatan Mencari Kebenaran (Pramana). Tersedia dalam https://wikakrishna.wordpress.com/2016/11/30/hindu-4-pengamatanmencari-kebenaran-pramana/ di akses tanggal 25 juni 2019.

Muncul Meme Polisi akan Tangkap TNI, Polri: Itu Hoax!. https://news.detik.com/berita/d4583704/muncul-meme-polisi-akan-tangkap-tni-polri-itu-hoax akses 25 Juni 2019.

Polri: Hati-hati, Sebar Berita Hoax Bisa Kena Pidana 6 Tahun. https://www.liputan6.com/news/read/2656966/polri-hati-hati-sebar-berita-hoax-bisakena-pidana-6-tahun. Akses pada Tanggal 25 Juni 2019.

Temuan Kominfo: Hoax Paling Banyak Beredar di April 2019. https://kominfo.go.id/content/detail/18440/temuan-kominfo-hoax-paling-banyakberedar-di-april-2019/0/sorotan_media, akses pada tanggal 25 Juni 2019. 